\title{
Alumni access policies in public university libraries
}

\author{
Natalie Burclaff ${ }^{\prime}$ \\ Langsdale Library, University of Baltimore, Baltimore, MD \\ nburclaff@ubalt.edu \\ Johannes Britz ${ }^{2}$ \\ britz@uwm.edu
}

School of Information Studies, University of Wisconsin-Milwaukee and University of Pretoria, South Africa

\begin{abstract}
This paper explores the current library access policies for alumni at a public university system using document analysis, observations and interviews. We found that alumni are specifically addressed in only two library access policies, and borrowing privileges through cards, on-site access and restricted access to electronic resources are common elements in the policies for community users. There are opportunities to expand and standardize services, and we recommend addressing alumni in policies as a separate user group.
\end{abstract}

Keywords: Library services, information access - alumni, university library services, public university libraries, university library policy.

\section{Introduction}

Nearly all public university libraries support life-long learning, but most seem to lose sight of an ever-growing user group: alumni. Students are shifted into community user status once they graduate, potentially weakening a tenuous relationship that public university libraries have with their students. As much time and effort is spent by libraries to attract student users, continuing a relationship with the students beyond graduation is a task left solely to the alumni relations department. Currently, most public university libraries are taking advantage of the online social networking boom, creating Facebook pages and Twitter accounts to connect with students (Harinarayana \& Vasantha Raju, 20I0).

In most cases the only 'friend request' an alumnus receives is to become a member of the Friends of the Library, which is also often their only portal into borrowing books and Interlibrary Loan Services. Library policies towards alumni certainly have room for improvement, and the idea that alumni can only become a 'friend' of the library through monetary donation creates an unhealthy exchange relationship, especially coupled with alumni expectations.

Certainly, some schools have a strong alumni connection, and their libraries reap the benefit (Konzak \& Teague, 2009). It is worthwhile to examine successful libraries and their relationships with alumni. Public university libraries must overcome the misconception that universities are primarily subsidized by government funding. In the university system examined in this study, only around 20 percent of the budget is supplemented by public taxes, already down from nearly 35 percent in 200I (University of Wisconsin System, 2000: I; University of Wisconsin System, 201 0: I). In addition, public university libraries have the additional expectation of providing resources for the general public - an expectation that many private university libraries do not have.

Public universities and their libraries must look to other forms of income, and with strong negative reaction to tuition hikes, turning to private donations is one solution. Alumni need to feel a connection to the organisation - in this instance, the library - that they are supporting. Policies can provide that connection for public university libraries. They act as intangible products, offering access to quality information, that are important in building an exchange relationship with alumni. By implementing a library policy that addresses alumni users, the library sets a framework by which to attract alumni through the other marketing elements.

The purpose of this study is to explore alumni access policies in academic libraries. In particular, this study will look at alumni policies of public university libraries and discover themes and trends in access policies. At this time, a working definition for alumni is 'students that have graduated from a university', and alumni policies will for this purpose be public documents that outline those university graduates' access to information.

While many parties can be involved in the development of alumni policies, including surveying alumni attitudes and beliefs, this study will focus on the administrative and library side of the alumni-library relationship. From the document analysis, observations and interviews, we illuminate common characteristics found in alumni policies to use as recommendations for an alumni policy.

I. Natalie Burclaff is Reference and Instruction Librarian at Langsdale Library, University of Baltimore, Baltimore, MD. USA

2. Johannes Britz is Interim Provost and Professor at the University of Wisconsin-Milwaukee, USA 


\section{Research objectives}

Our research seeks to explore the access policies at public university libraries and the implications of alumni access. To that end, our research question is:

What components exist in alumni access policies at public university libraries?

This general research question allows for the exploration of multiple facets including different types of access provided for in policies, a comparison between written policies and observations in gaining access as an alumnus, and the relationship between alumni and the library in a micro-environment.

In order to explore these topics and answer our research question, this paper is structured as follows. A literature review provides a chronological overview regarding non-affiliated users' access to materials and services at university libraries, followed by the methodology, which outlines the research strategy, approaches and data analysis used for our research. The results and analysis section reports the information gathered using document analysis and observations to examine the components of access policies, and interviews, which take a narrative look at the relationship between alumni and the library. This is followed by the discussion section that seeks to answer our research question and provide further implications of alumni access policies in public university libraries by applying our research to Anderson's long tail theory (2008) and Caladini's theory of influence (2008). Our conclusion summarizes our main findings and suggests future research questions.

\section{Literature review}

Organizational policies, rules and regulations have shifted in libraries to accommodate advances in technology. Technology influences access, and in turn forces policy-makers to reexamine access standards, especially now that electronic access is a greater commodity than physical access.

Immediately following World War II, academic libraries sought to increase public relations and goodwill by allowing unaffiliated users access to material (Courtney, 200I: 473). Waggoner discussed trends he had observed at Duke University library, especially the increase of unaffiliated users at university libraries due to the budget shortfalls of public and school libraries (1964: 55-57). For the purposes of public relations, he believed access policies should support all types of users, as long as there are enough resources for academic libraries to support their primary users, which are defined as students and faculty (Waggoner, 1964: 55-57).

As university library budgets fell, some universities were forced to restrict access to their materials. Kaser (1974) focused on the problems that arise from what he calls 'scholarly mobility', which is when researchers or other scholars use the services of libraries with which they are not affiliated. The unaffiliated user is defined as a heavy user that has a higher than average service cost, based on the fact that this user has made a special trip to come to the library. Many unaffiliated users hold the belief that public information should be free and equally accessible, but in reality information always has a cost associated with it. Kaser proposed a more comprehensive interlibrary loan program as a solution that is aimed at both public and academic libraries. While Kaser stressed interlibrary access over interlibrary loan to save costs, he could not foresee the problems with database licensing and electronic journals (1974: 283). Academic libraries in the 1980s not only had physical access to contend with, but also electronic access as more and more databases were introduced to facilitate research and searching of journals (Courtney, 200I: 473).

Giving access to unaffiliated users became increasingly difficult as the budgets could not meet the demand for materials for primary and secondary users (Ferguson, 2000: 85-86). Surveys on access were frequent in the 1990s as many universities tried different policies (Mitchell, 1992; Russell et al., 1992; Bobp \& Richey, 1994). Three different responses to public demands were: continuing to provide open and equal access, closing the library completely to unaffiliated members, and creating tiered access policies (Bobp \& Richey, 1994). Findings from the survey of California Public Universities found that although tiered access policies were the most beneficial, they were the hardest to implement (Bobp \& Richey, 1994).

Mitchell gathered survey results from 49 library directors at four-year public academic colleges and universities in urban areas. The survey showed that virtually all libraries allowed on-site access, but external users were either not allowed to borrow books or had to pay a fee. The borrowing privileges, after a fee payment, were similar to those for undergraduate students. However, late fines and unreturned books were sought after more aggressively than those of affiliated members. Overall, 75 percent of library directors were satisfied with their external user policies (Mitchell, 1992).

Another survey was issued by Russell, Robison, Prather and Carlson (1992) to determine the level of access that nonaffiliated users had in 18 urban academic libraries. The survey asked questions about checkout privileges, in-house use of materials, reference assistance and library services for external users, defined as 'patrons with no affiliation with the 
institution', which in this case does not include alumni. The authors concluded that these urban universities were strongly committed to meeting the needs of their external users as reflected in their policies and practices (Russell et al., 1992).

However, not all users are satisfied. Cohn compared using a restrictive one-day visitor's pass to 'begging for one's intellectual food' (1993: 184). Another user saw cutting off alumni from interlibrary loan access as a form of information censorship (Groninger, 1995: 23). One recent concern has been distance education students, who may need to find resources locally when institutions fail to meet guidelines on providing distance education library materials (Barsun, 2002: 95). Many times, because the student is affiliated with a different institution, they have limited access at a local university.

Lynch (2003) proposed that institutions of higher education have fostered an environment of quality information, but completely cut off access after graduation. Alumni are no longer affiliated with a university and therefore do not have access to material post-graduation and content providers do not offer individual consumer packages (Lynch, 2003: 12). One solution is for libraries to create 'information resource homepages' for alumni that provides links to free resources on the Internet (Ferguson, 2000: 86). Most state-funded university libraries have policies that permit onsite usage for the public. Lynch argued that individuals will no longer be able to engage intellectually due to restrictive electronic access policies. He concludes that having access to printed journals and books is not sufficient in a digital age and calls for research to investigate how much access is lost outside the university (Lynch, 2003: I2-13). Britz and Ponelis (2005) used John Rawls's principles of social justice to argue that the right to information is a basic right. To avoid information injustice, people must have access to a minimum amount of information (Britz \& Ponelis, 2005). While their paper is presented in the context of access to information guidelines in developing countries, it can also apply to the concerns of Lynch, that access to scholarly information is increasingly restricted after graduation (2005: I2-I3).

As more universities have sought to provide access to their alumni or alumni associations, many descriptive studies on the implementation of access were published (Wells, 2006; Smith, Street \& Wales, 2007; Horava, 2007, Wetherill, 2008). Around the United States, university libraries have various alumni access policies. For example, one gives remote access to library databases such as EBSCOhost to alumni, but does not offer print material check-out (Carlson, 2006: A43).

Smith, Street and Wales (2007) outline the Open University's project to give electronic access to alumni. Uniquely, because Open University is an online university, on-site access is not an option. After one year of studying the new electronic access service for alumni, the authors came up with four conclusions: first, some licensing agreements allow alumni access already, second, proxy servers should be used for authentication, third, libraries must create partnerships with alumni associations, and fourth, prior to providing service, a survey of alumni on their information needs is helpful, but their answers are not always conclusive. This study segments alumni needs and focuses on alumni of their MBA program, which may show that alumni of certain majors or colleges may have different information needs, and that a onesize-fits-all option may not be ideal (Smith, Street \& Wales, 2007).

Another case study found that that funding, working with licensing databases, and advertising are important when giving alumni database access (Wells, 2006). The author believes, although does not prove, that alumni access to library information will strengthen the alumni-library relationship and contribute to 'lifelong learning' of alumni. Wells suggests that alumni as a user group are an untapped market for libraries and libraries should offer electronic access before vendors dominate this new market (2006: 4I3).

Horava (2007) used the long-tail phenomenon to explain the low appeal in giving alumni access to only one database. The long-tail phenomenon states that a lot of people will buy a few items, but a lot of items will be purchased by a few people (Anderson, 2008). In terms of purchasing information, this means that different users will be interested in a wide

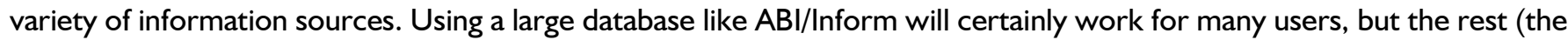
tail) will have different information needs, which is an important consideration when looking at creating alumni access that takes a one-size-fits-all approach (Horava, 2007).

The motivation behind creating online access for alumni at Cranfield University Library was the demand from alumni to have continued access to these resources post-graduation. Second, Cranfield University was interested in maintaining the relationship that they had built between the library and the students (Wetherill, 2008). The reasoning behind providing online access to alumni was to brand them as a 'privileged' and 'special' user group, without giving preference to those within reach of on-site access.

Cranfield University Library sought to give online access to all alumni and not segment their market. Alumni could register using online application and renewal forms and online payment. Also interesting was the tiered package offered to alumni ranging from free services to paid subscriptions for full content. The author found former students often focus on what resources have been eliminated rather than the resources made available. The university concluded that this program was still important to their mission of life-long learning, and plan to continue it in the following years (Wetherill, 2008).

Inkanyiso, Jnl Hum \& Soc Sci 20I I, 3(I) 
Most recently, Joseph (2008) discusses open access policies as a way to disseminate information to the general public. The author examines cost in a new way, since libraries' open access to all patrons is cost-prohibitive. Instead, policies are being created that allow academic researchers to place their material for scholarly publication in an organizational repository. Policies and petitions are being implemented at a grassroots level by researchers and librarians instead of coming top-down. Joseph concludes that publishing policies are becoming more flexible in terms of open access, which benefits both the institution and the user (2008: 105).

Alumni access has shifted as resource demands have changed in academic libraries. Although some research has been done on alumni access, none have explored access policies in terms of a marketing strategy to maintain the relationship between alumni and library. By examining the access policies, observing the policies in practice and interviewing three key policy makers in the library-alumni relationship, we provide insight in using access policies as a marketing approach to reach alumni.

\section{Methodology}

\section{Research strategy}

The research strategy is a qualitative approach to case study. A case study examines a particular program in depth and seeks to answer a research question within the context of its environment (Yin, 2003). Creswell defines a case study as a research method that 'explores in depth a program, event, activity, process or one or more individuals' and is constrained by the duration of activity or a specified amount of time (2009: 13). In this study, we explored present alumni access policies at libraries in a state university system. Case study is the best method in that it is exploratory research of alumni policies, constrained by the present day issue of electronic access. We used a multiple case study format to find general trends and themes in alumni access policies and then focused on one specific case, a public university library within that system that does not has any current alumni policies. Multiple case studies are used when multiple phenomena exist (Powell, 2004). In this case, many public university libraries have alumni access policies or different ways of approaching the issue of alumni access, making multiple case studies an appropriate method for this research.

Case study method is also useful when a phenomenon has not been well researched, and in this instance, alumni access policies have enjoyed little empirical research. In addition, using a qualitative method is especially useful since the overall intent of the research, after discovering trends and themes across multiple cases studies, is to create policy recommendations for the focus case study library. This purpose falls within applied research, which is most often done through qualitative measures (Creswell, 2009).

The case study is composed of document analysis, observation and interview methods. The document analysis using the content analysis approach will consist of alumni policies of the higher institutions in a state university system, known as System $U$ for the purposes of this study. System $U$ has 13 four-year public universities, with a wide range of demographics. In addition, a public university system was chosen because those libraries must also address the community user group that most private universities do not have.

Observations take place over the phone. We devised a scenario where we presented ourselves as alumni of each university and called to obtain information on how we could access a scholarly article from the database JSTOR. JSTOR was chosen because all 13 university libraries subscribe to this database and it consists of many full text articles. We observed the described actions and suggestions the reference worker did and offered, and the information was coded based on common groups of observations.

The case study specifically examines one school within System $U$, which currently does not have an alumni policy. University Library E is a four-year university located in a large Midwest city with student enrollment at close to 30,000 . The number of current living alumni is at 97,000 . Interviews took place with the director of University Library $E$, the library development director and University E Alumni Chapter Coordinator. The interviews with administrators provided further understanding in the area of alumni access policies not discernible from the content analysis. The interviews were used as supplemental support and to explore other areas of alumni access policies.

Methods of achieving validity

The use of case study as a research method has been seen as having low internal and external validity, which is why it is important to have at least three types of data collection (Powell, 2004). This triangulation in data collection creates validity by building coherent themes from several different sources of data (Creswell, 2009). We also removed potential bias by including data that is situated outside of the general themes to present a holistic picture to the reader. In addition, validity is added by presenting our results in detail, which presents a level of specificity in our findings and creates a deeper experience. 


\section{Participants}

Using the multiple case study format, we selected our participants based on the population that aligns with our prespecified criteria. Our criteria were four-year public universities within State University System U. It is necessary to use a state university, because unlike private universities, public university libraries often have to meet resource needs of community users in addition to their other primary user groups. A state university system was chosen because of the potential for related resources and policies to use as comparison. It was not required that these university libraries have a current alumni policy, nor any outreach programs with their alumni. This state university system has 13 four-year public universities.

The focus of this case study is University Library E situated in an urban city with a population of 500,000 . Their student enrollment is close to 30,000 and the library does not have a current alumni policy. Since our primary form of data collection is document analysis, participants are the libraries themselves. We interviewed three administrators, since the purpose of our research is to explore the library side of the alumni-library exchange relationship through policies. We chose the most relevant people to interview, using a purposeful method of sampling: the director of the library, the library development director, who coordinates outreach events and works with donors, and the university alumni chapter coordinator.

\section{Data analysis strategies}

For the three methods of data collection - document analysis, interviews and observations - we used Creswell's six-step data analysis plan (Creswell, 2009: 185-190). First, we organized all the data we collected, including transcriptions, field notes and document analysis notes. We then read through the data to gather an overall meaning, followed by coding documents, transcripts and filed notes by hand to illuminate trends. Because this is an exploratory case study, much of the coding cannot be mapped prior to data collection (Powell, 2004). Prior to coding the document analysis dataset, a similar external use library policy was coded based on certain themes as a pilot test for my criteria (Neuendorf, 2002). The coding provided a comprehensive description of the case study context and situation and highlighted themes. The last two steps of qualitative data analysis were applying the themes to theories and providing an interpretation of the data. We applied those themes to Robert Cialdini's influence theory (2009) and Chris Anderson's long tail theory (2008), both of which has implications for marketing and relationships. Cialdini's influence theory consists of seven major principles reciprocation, commitment, social proof, liking, authority and scarcity - that influence our behaviors because they create an automatic reaction from us (2009). Anderson's long tail theory states that although many people buy a lot of one or two popular items, many niche items are bought by one or two people. This theory shows the economic viability of Internet-based stores that have little overhead but access to many specific items (Anderson, 2008). These theories will be able to demonstrate what importance, if any, alumni access policies can have on alumni-library exchange relationships.

\section{Results and analysis}

Policy content analysis

A content analysis of user policies on each university library website was conducted. The primary goal was to investigate alumni access policies, but because many libraries in this system lacked policies directed specifically toward alumni, any external user policy sufficed. To increase validity, two rounds of analysis were conducted two weeks apart to determine the solutions and code them. The audience for whom the 'external' access policies were created was also examined. Similar results were obtained in both cases. The location of policies on each website varied greatly. When information is not located under an intuitive label, it can be difficult for users to find the information. From the 13 public university libraries in this study, there were 14 links that conveyed basic policy information. Six of those links used the term policy, while six links addressed the user group using labels such as community and visitors - one of those was distinctly labeled alumni. Two links were labeled borrowing.

The content analysis revealed that 12 out of 13 libraries offer a user card to non-affiliated users. The cards primarily give borrowing privileges, but interlibrary loan, catalog and electronic resource access as well as physical access were all examined. Between the 12 libraries that offer a card, there are 18 different card names. Prices ranged anywhere from free to $\$ 50$. Generally, the pricier cards correlate to Friends of the Library cards, libraries in higher population areas, and cards for out-of-state residents. Within the list of card names, there are various pricing levels. Table I shows the different characteristics of each card. Whenever there were different pricing strategies for one card, levels were arbitrarily assigned.

Inkanyiso, Jnl Hum \& Soc Sci 20I I, 3(I) 
Table I

\begin{tabular}{|c|c|c|c|}
\hline Name of card or group & Price & Renewal? & Stipulations \\
\hline Special Borrowers card & Free & 2 years & $\begin{array}{l}\text { 'Area residents may obtain a special borrower's card at the Circulation Desk } \\
\text { on the main floor of the library by filling out an application and presenting one } \\
\text { form of photo identification'. }\end{array}$ \\
\hline Special Borrows Permit & Free & I year & Meet certain user groups \\
\hline Library Special Borrowers (Level I) & $\$ 15$ & I year & A state resident 18 years of age or older with valid ID \\
\hline Library Special Borrowers (Level 2) & $\$ 15$ & I year & Local middle and high school students \\
\hline Library Special Borrowers (Level 3) & $\$ 30$ & I year & Non-state residents $18+$ \\
\hline County Public Library card & Unknown & Unknown & Unknown \\
\hline Annual Fee Card & $\$ 30$ & I year & $\begin{array}{l}\text { Two current forms of identification showing state residency (one must have a } \\
\text { photo) }\end{array}$ \\
\hline Community Borrow Card (Level 2) & $\$ 50$ & 2 years & $18+$, valid [neighboring state] library card \\
\hline Community Borrower Card (Level I) & $\$ 25$ & 2 years & $18+$, valid state library card or state property tax statement \\
\hline Community Borrower Card & $\$ 10$ or $\$ 25$ & 1 year $/ 3$ & $\begin{array}{l}\text { State Residents } 18 \text { years or older with a valid state driver's license or state } \\
\text { picture ID (and are not in high school) }\end{array}$ \\
\hline Community Card & Free & Unknown & $\begin{array}{l}\text { * Cards are issued only to individuals. } \\
\text { * Persons I } 8 \text { years or older living or working in the following counties. } \\
\text { * University Alumni, and Faculty Emeriti. } \\
\text { * Local High School 'A' Honor Roll students. } \\
\text { * Current State driver's license, or } \\
\text { * State Identification card. }\end{array}$ \\
\hline Community User Card & $\$ 20$ & 2 years & Photo ID, State resident \\
\hline Corporate Card & $\$ 30$ & I year & Letter on stationary granting permission and responsibility from a corporation \\
\hline Courtesy Card & Free & Unknown & proof of affiliation and ID photo (does not include alumni) \\
\hline Friends of ___ Library & $\$ 25$ & Unknown & None \\
\hline Friends of the ___ Library & $\$ 35$ & I year & None \\
\hline Friends of the Library Card & $\$ 25$ & I year & None \\
\hline Guest card & Free & Unknown & $\begin{array}{l}\text { 'You must be eighteen years of age and present a valid driver's license or state } \\
\text { identification card'. }\end{array}$ \\
\hline $\mathrm{N} / \mathrm{A}$ & $\mathrm{N} / \mathrm{A}$ & $\mathrm{N} / \mathrm{A}$ & $\mathrm{N} / \mathrm{A}$ \\
\hline NEW ERA & Free & I year & I8+, valid state ID \\
\hline NEW ERA Card & Free & Unknown & $\begin{array}{l}\text { Application form and present a valid state identification card, such as a driver's } \\
\text { license }\end{array}$ \\
\hline None specified: Community borrower & $\$ 20$ & Unknown & $\begin{array}{l}\text { Community borrowers must show some a picture I.D. to obtain a community } \\
\text { borrower's card. If a picture I.D. is not available, a form of I.D. that shows a } \\
\text { current address will be accepted, at the discretion of the Desk attendant. }\end{array}$ \\
\hline
\end{tabular}

Of the 20 known prices for borrowing cards, seven are free. Thus, the mean price is $\$ 11.50$, and median is $\$ 17.50$. Looking only at the libraries that do charge for borrowing access, the mean price is $\$ 25.30$ and the median is $\$ 25$. The renewal periods are known for 14 of the cards. Ten have a I-year renewal, and four have 2-year renewals. One of the year-long cards has an option of paying a discount price for 3 years.

There is no stipulation for a Friend of the Library card - as long as a person pays, access is granted. For 15 card descriptions, it is indicated that a picture ID is needed. More libraries indirectly imply an ID is needed, such as borrowing cards that require proof of a certain affiliation. Seven require proof of state residency; for one library, state residency is optional as long as other requirements are met. One allows for a patron with a neighboring state ID to get a borrowing card, and one allows for anyone outside the state to get a borrowing card for a premium. Six require borrowing card holders to be over 18. Only one card stipulates that one possible affiliation can be alumni of the university.

For borrowing and loan privileges, one library was excluded because it did not address any external users in its policies, and three other libraries were excluded because although they had external user policies, no borrowing or loan privileges were listed. For the remaining nine, they all allow borrowing card users to check out books for 28 days, which is the same as undergraduate students. Four of the nine indicate that media materials can be checked out.

Access to services was examined in four areas: Interlibrary loan access, catalog access, physical access and access to electronic resources. Eight university libraries' policies explicitly inform external users that interlibrary loan services are Inkanyiso, Jnl Hum \& Soc Sci 20 I I, 3(I) 
not provided. Five recommend using one's primary institution, whether it is a school or public library, to get access to materials. Only one library offers interlibrary loan to external users through a fee-based model, and one library gives interlibrary loan privileges to Friends of the Library at a \$ 50 giving level. While every university library catalog in this state university system can be accessed remotely by any user with internet access, only four libraries clearly reveal this information. Two mention accessing the catalog on-site, but not remotely, and one recommends using the public library to search the university collection. In addition, all of the libraries examined offer physical access to their library, but only six give this information in their policy. One library does mention restricted access, in that during overnight hours, from I I pm to 7 am, the library is only for university ID holders.

As per the literature review, access to databases is one of the highly contended forms of access that non-affiliated users seek. However, the cost of databases and licensing is prohibitive and none of the I 3 libraries in this state system offered remote access to external users. We closely examined the word choice used in library policies related to electronic resources. Our variables were: how the library described their electronic resources and described their audience, reasons given for limited access and the language used, and suggested solutions to restricted access.

While the specific terms used were never identical, seven referred to their electronic resources as databases, while five referred to them as resources. More important was the sense of ownership implied by the word usage. Five libraries used library, as in library databases or library resources. Additionally, the words owned, licensed and subscription were each used once. These words of ownership can convey that the electronic resources are privileged and not free. While rhetorical analysis can be unreliable (Neuendorf, 2002), examining the positive and negative connotations when addressing users provides insight to this study on alumni-library relationships. The same content analysis procedures were applied, and after multiple rounds, the results were the same. We acknowledge that no researcher is completely unbiased, that content can have various, simultaneous interpretations depending on the receiver (Krippendorf, 1980). Figure I summarizes the spectrum of how libraries address their audience in electronic access policies.

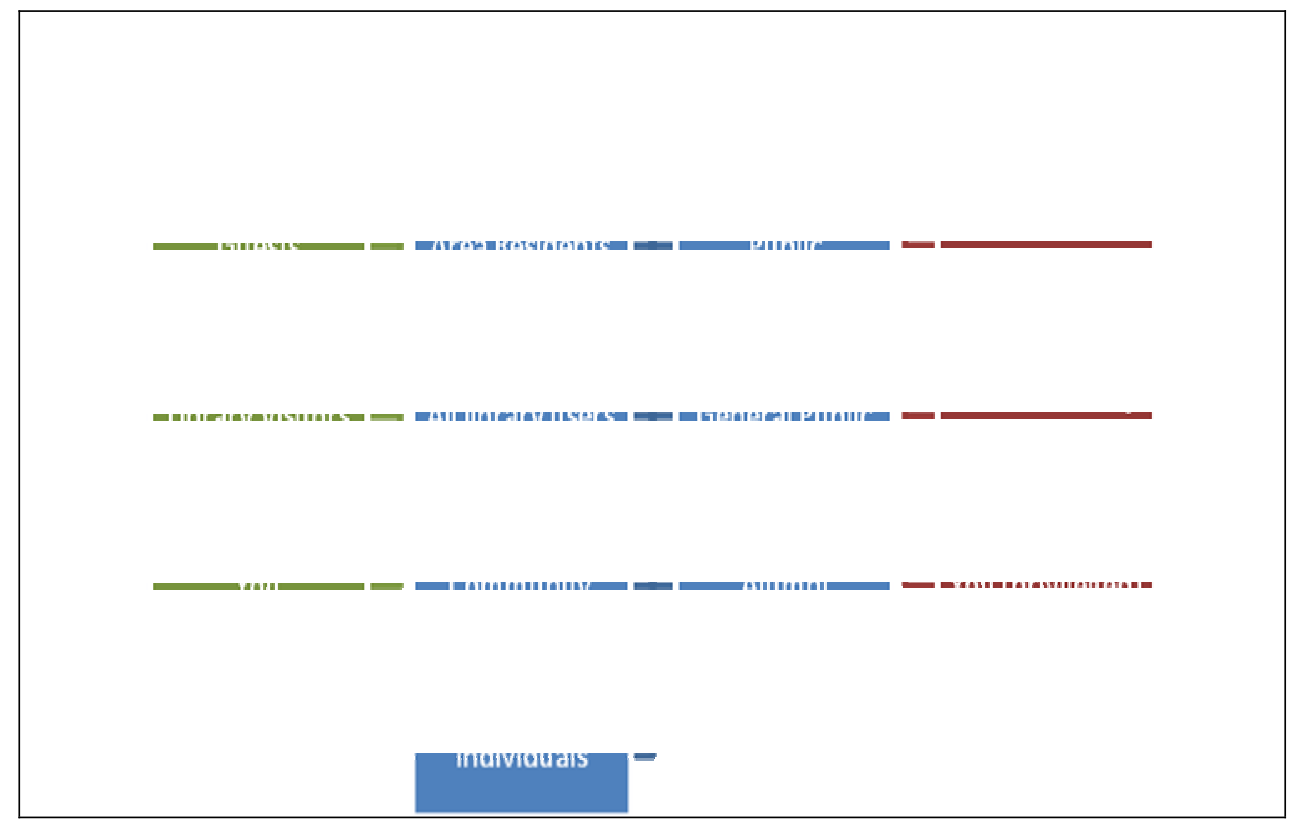

Figure 1 Audience coding

Two libraries did not have electronic resource policies pertaining to external users. Three libraries used two different audience terms. Two of those libraries used only neutral terms, while one library used a neutral and negative term. One library listed its electronic resource policies for external users in terms of what internal, or primary, users were allowed to do. This avoids a negative policy, which would state what external users are not allowed to do. Those internal users were addressed as 'you'. The 'you' title is a more direct and intimate way to communicate policies for the privileged, internal users.

Seven libraries do not give any reasons for restricted access. The remaining six give multiple reasons. Licensing agreements is used six times as an explanation for restricting resources. Licensing restrictions is used twice. One library uses terms and conditions without mentioning licensing, and another library that does not mention licensing explains that Inkanyiso, Jnl Hum \& Soc Sci 20I I, 3(I) 
'independent providers are protected by copyright and other laws'. Additionally, one library explains that access is restricted unless one has an alumni membership. The most unique explanation for a restriction of access is Library C, which states that electronic resource access is limited 'due to the demand on finite library resources', and does not mention licensing or other agreements. This phrase can imply the lack of funds the library has to give to secondary users, such as alumni, but because it is not explicit, this conclusion cannot be made definitively.

One library quoted their mission statement, and most interestingly, two referred to the University System Policy on Use of University Information Technology Resources. It raises questions on why not all of the university libraries acknowledge the System access policy to some degree, especially since many of them share similar electronic resources. It is understandable that, due to budget constraints and size of the institution, policies would be augmented for each specific library. Because the libraries in this university system unanimously do not offer off-campus access to external users, it is worth examining whether libraries offered solutions to restrictive access and what those solutions were. Figure 2 displays the general categories that II libraries offered as suggested solutions.

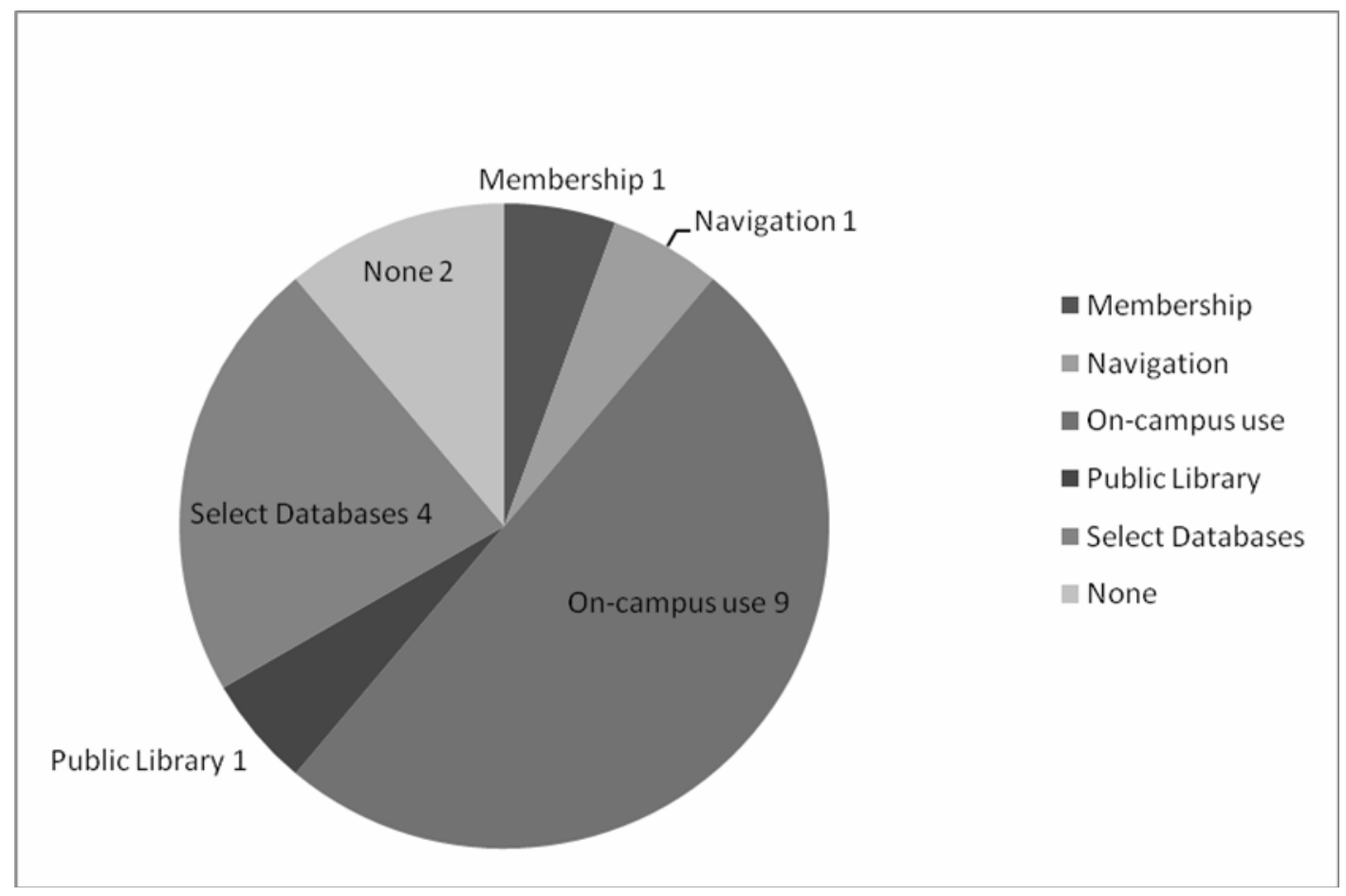

Figure 2 Suggested solutions to restricted access by type

The majority of libraries suggested that users come to campus for on-site use of electronic sources. The next most frequent suggestion was to look at a list of select databases that are publicly available through the state. Three unique suggestions were to become a member of the alumni association for access, navigate to another website about access, and use or request the material at your public library. The fact that all libraries with electronic resource policies have suggestions for external users to get access demonstrates a common quality of policies in this particular university system.

\section{Reference observations}

For the purpose of making observations in a natural work environment, we identified ourselves as an alumnus of each campus in a phone call to each library's reference department. Questions were posed from a scenario we created, in that we were trying to gain full-text access to an article in JSTOR. After noting the reference departments' responses and problem-solving statements throughout the telephone dialogue, we coded the audio observations into the following categories: Statements on whether full-text access was permitted, reasons given for allowing or not allowing access, any mention of physical access, potential solutions offered to get the article, and other observations. The category of physical access overlapped with potential solutions, but we thought it was important to make a note if physical access to the library was mentioned because of our prior knowledge that all the campuses observed allow community users to use their libraries on-site. 
Ten of the 13 libraries observed via phone calls were direct in their reply of 'no access' for alumni. One library worker was not sure of the answer, one library replied with the stipulation that if we joined the university's alumni association, and one library answered in the affirmative, stipulating that we needed to be able to log-in with a valid ID. Only 9 libraries in the consortium gave reasons for the lack of access: Four of those explained that it was simply that fact that alumni are no longer students. In addition, one pointed out that alumni also do not have access to e-mail. The other five included financial reasons, such as the cost of databases or cost of licensing as barriers to access.

Another observation was that most universities assumed we were located outside of easy driving distance - this was concluded based on the fact that seven libraries did not explain on-site accessibility unless prompted. The other four used on-site access as a solution to the problem. Other solutions included offering to send the article as an attachment ( 2 libraries), going to a local public library to request it through ILL, going to a nearby university to get database access (2 libraries), or going to the alumni page to pay dues or explore alumni access (2 libraries).

There are some general observations that we noted when calling all the university libraries. First, the hours that the reference desk staff was available for questions vary. Many answers were dependent on the reference worker, such as librarian versus student worker. Frequently, librarians were not available on the weekend - either a recorded message was played or student workers answered the phones, with less knowledge about user groups and databases.

\section{Interviews}

Three semi-structured interviews were conducted at Library E, which currently does not have an alumni access policy. One researcher interviewed the library director, alumni association director and library development director. The interviews were voice-recorded and then transcribed. The purpose of the interviews was to further explore how alumni and the library interact, including past relationships, outreach initiatives and current relationships, and future aspirations. Because only three interviewees were selected at one library, the interviews were meant to provide a narrative, human element in a micro-environment. It was not possible to correlate the information gathered from the interviews to the other data collected but it gave further insight into alumni access policies.

Both the library director and the alumni association director in separate interviews discussed the changing definition of alumni at University E. Prior to 2005, to become part of the alumni association, dues were required. In exchange for these dues, access was given to library materials and borrowing privileges. After 2005, to expand the alumni membership, dues were no longer required. However, this uncoupled the library privileges from these new alumni. The alumni association director then mentioned high levels of membership within the association. At a price, alumni can gain library materials. The library director discussed the level of Friends of the Library membership. For \$35, 'a pretty reasonable amount', alumni can join the Friends of the Library and be able to borrow books from the library. At higher levels, they can also access interlibrary loan.

Currently, the alumni association director reaches out to alumni through newsletters and e-newsletters. The development director of the library mentioned that the library recently made a connection with the alumni association to include the library in their e-newsletters. Before that, only donors were notified of library events and other opportunities to support the library. In addition, according to both the library director and development director, the library is planning on sending Friends of the Library mailings out to alumni living in the zip codes closest to the library. This seems beneficial because at this time, the library can only offer on-site access to materials. The alumni association director also connects to alumni through the university alumni website and through the social network site, Linkedln. The library director did discuss an ongoing suggestion in regards to creating an alumni page. The page would give a list of databases that are freely available either because they are public resources or because the state has purchased access for all of its residents. However, the alumni association has not actively started to create that site and the library director admitted that perhaps the library should take initiative on creating it.

The development director, by description of the job, is focused primarily on the donor relationship with the library. Development directors exist for every school or college within a university (i.e. the School of Business). Because the library is a university-shared place, alumni 'belong' to the development director of their graduating school. The key, according to the development director, is collaboration. When another development director finds their prospective donor also has a strong emotional connection or interest in the library, they 'share' the donor. In the end, the university, as a whole, benefits. The team of development directors and alumni association has the common goal to 'engage and bring back alumni to campus'.

In the future, all three interviewees mention collaboration as a way to best build the alumni-library relationship. The development director highlighted collaboration with the Friends of the Library, other schools within the university and the alumni association to reach out to alumni and to encourage them to give back to the library. The alumni association director found that there is a strong need from alumni to want to access library resources, especially immediately after Inkanyiso, Jnl Hum \& Soc Sci 20I I, 3(I) 
graduation. The hope is to collaborate with the library to provide those resources in the future, and to collaborate on events that specifically focus on alumni. The library director was also looking at collaborating with the alumni association, especially in terms of letting alumni know what materials they can access for free.

\section{Discussion}

Using our findings, we can now answer our main research question: What components exist in alumni access policies at public university libraries? Through our content analysis and observations, we found that most library policies in the University System $U$ that were related to alumni access were actually listed under community or non-affiliated user policies. For the most part, they provided borrowing access through a library card that was often tied to a price or a location, such as state residency. All universities allowed for on-site access, but very few could provide electronic access to materials off-site due to licensing agreements. The written policies available on websites were often addressed in a neutral manner, but only two libraries used 'alumni'. Our observations confirmed our findings that alumni do not have access to electronic resources except in certain databases and confirmed the solutions to getting access, such as signing up for a membership card, that were noted in the written policies. Solutions seemed to be an important, positive component of policies that encouraged non-affiliated users, both from the community and alumni, to use library resources.

The interviews provided insight to underlying components of access policies, which is the relationship between the alumni association and the library. On a micro-level snapshot of one public university library in the studied system, the library would like to do more to reach out to alumni, both to make an emotional connection and financial support. While many methods of reaching out to alumni were mentioned by the library director and the library development director, including mailings and events, neither one saw policies as a primary tool to make a connection with alumni. It was noted by both the alumni association director and the library director that there was a strong connection due to the past agreement where alumni could get access to library materials and services by becoming a lifetime member of the alumni association. However, with the advent of electronic resources, it is difficult to meet all the needs of current alumni, who still request access to library materials. One potential solution is to highlight services that are freely available to alumni, mostly through state-funded databases.

Applying policies to the long tail theory

Public university libraries are forced to segment their user market in primary and secondary users. As is evident in many of the policies, observations and interviews, libraries in the university system in this study are striving to accommodate both groups. However, alumni can find themselves caught, or even lost, in between these two user groups as they transition from primary to secondary users. Chris Anderson's long tail theory shows that many people buy a lot of one or two popular items and a few people buy only one or two of many different, less popular items (2008). In a time where everything is customizable and online stores have nearly limitless storage and hardly any overhead costs, a supplier can segment its market to just one person. The long tail discusses the declining interest in mass market appeal and instead catering to the needs of a few (Anderson, 2008). This may mean that libraries have the opportunity to further segment or refine their user groups, and their policies should reflect this. Applying the long tail theory to answer the main research goal of this study, this means that the ideal access policy not only appeals to alumni as a whole, but different segments of alumni based on graduation year or major.

Additionally, where some libraries offer free borrowing cards and others cost money, the state university system could pool resources to support their alumni as a whole and offer a tiered system. Many alumni may opt for the free option where they have on-site access and the capabilities to check out a few books. Fewer alumni may decide to purchase access with additional benefits of virtual reference, longer loan periods and more books. Even less may decided to purchase, at a higher price, access to interlibrary loan and a select number of databases. At a certain point, however, is the problem with licensing. The library can never truly be a long tail market for alumni and other users because publishers and databases restrict their databases in ways that prevent the library from finding a model that would charge one person to access ABI/Inform, one person to access JSTOR and ten to access LexisNexis without a loss.

That one-to-one purchasing is usually because a person finds something specific that they are looking for. Alumni may come across information they need, perhaps an article they want in full text, and the university library can position themselves as resources or suppliers of that information. Libraries need to build a connection with alumni, and one message that does that is policies. By having open policies and marketing them to alumni, signally them out from the rest of the community members, the message is that alumni are meaningful.

Applying policies to the theory of influence

Robert Cialdini (2009) presented a theory of influence to help business and organizations create an exchange relationship with its consumers. Cialdini studies how certain triggers, which he groups into principles, can cause reactions in human 
behaviors. These 'click, whirr' responses can be applied to any one of six principles that Cialdini introduces: reciprocation, commitment, social proof, liking, authority and scarcity. Libraries can use Cialdini's theory to influence alumni into using and supporting the library. For the library-alumni relationship examined in this study, the two principles that best apply are liking and scarcity.

The liking principle is defined by several factors including familiarity and association that can have a subconscious effect on people (Cialdini, 2009: 170). This principle can be applied to library policies. First, users like things that are familiar, so it would make sense for libraries to institute policies that are familiar to alumni in terms of access and borrowing periods for materials. The factor of association can be difficult in this situation because in general policies can be associated with rules and restrictions. Wording library policies so that they focus on what the library has to offer alumni and giving potential solutions to restricted access will help to reverse the negative association users have with policies. In addition, frontline staff should also avoid using 'policy' as a synonym for 'restriction'.

Libraries can also use policies to influence alumni relationships through the scarcity principle. The scarcity principle states that 'opportunities seem more valuable to us when they are less available' (Cialdini, 2009: 200). Most recognizably, this principle is used in advertising to alert customers that there are limited supplies (Cialdini, 2009). However, the scarcity principle can be applied to library policies aimed at alumni. By positioning library resources as scarce commodities in policies, similar to how the libraries in this study explain the restrictions because of licensing, working with the library may seem even more appealing. Alumni can understand through policies that there is high demand and cost for scholarly sources, and therefore even minimal access can appear to be gracious.

\section{Conclusion}

Libraries in this university system have the additional pressures of balancing the needs of their primary users - students, faculty and staff - with the wants of their secondary users. The problem is that upon graduation, students become alumni and transfer into that second group of users, along with restricted access. While university libraries certainly cannot grant equal access to everyone in any place because of licensing agreements and cost, this study explored how these libraries position their policies to maintain the connection with past students. It was discovered that only two libraries in this system address alumni specifically. However, their policies towards external users all contain similar elements, such as borrowing privileges, interlibrary loan privileges, physical access and electronic resource access. Using the long tail theory of marketing and the influence theory to analyze the results, it is recommend that the libraries in this system rewrite their policies to maintain and build upon their relationships with alumni, which can benefit libraries not only through word-ofmouth recommendations and commitment, but also through financial support in the future. Future studies should examine policies across the country and a comparison between private and public universities may provide additional insights.

\section{References}

Anderson, C. 2008. The long tail. New York: Hyperion.

Barsun, R. 2002. It's my library, too, isn't it? Journal of Library Administration 37 (I/2): 59-82.

Bobp, M.E. and Richey, D. 1994. Serving secondary users: Can it continue? College \& Undergraduate Libraries I (2): I-I6.

Britz, J.J. and Ponelis, S.R. 2005. Guidelines for fair distribution of scholarly information. Mousaion 23 (2): 230-24I.

Carlson, S. 2006. More colleges move to offer online library materials to alumni. The Chronicle of Higher Education 52 (34): A43.

Cialdini, R. B. 2009. Influence: Science and practice ( $5^{\text {th }}$ ed). Boston: Pearson.

Creswell, J. 2009. Research design: Qualitative, quantitative and mixed methods approaches. $3^{\text {rd }}$ ed. Thousand Oaks, CA: Sage Publications.

Cohn, W. 1993. Private stacks, public funding. American Libraries 24:182, 184.

Courtney, N. 200I. Barbarians at the gates: A half-century of unaffiliated users in academic libraries. The Journal of Academic Librarianship 27 (6): 473-480.

Ferguson, A. W. 2000. Back talk--alumni remote access to online resources. Against the Grain I2 (4): 86, 85.

Groninger, S. 1995. Books effectively censored: Discrimination at a university library: Alumni the target. Journal of Interlibrary Loan, Document Delivery \& Information Supply 5 (3): 23-26.

Harinarayana, N. and Raju, N. 2010. Web 2.0 features in university library web sites. Electronic Library 28 (I): $69-88$.

Horava, T. 2007. Licensing e-resources for alumni: Reflections from a pilot project. College \& Research Libraries News 68 (7): 437-44I.

Joeseph, H. 2008. A question of access - evolving policies and practices. Journal of Library Administration 48 (I): $95-106$.

Johanson, G. 199I. Information beyond graduation. The Australian Library Journal 40 (4): 314-319.

Kaser, D. 1974. Library access and the mobility of users. College and Research Libraries 35: 280-284.

Konzak, E. and Teague, D.P. 2009. Reconnect with your alumni and connect to donors. Technical Services Quarterly 26: $217-225$.

Krippendorff, K. 1980. Content analysis: An introduction to its methodology. Beverly Hills: Sage Publications.

Lynch, C. 2003. Life after graduation: Beyond the academy's digital walls. Educause Review 38 (5): I2-I3.

Mitchell, E.S. 1992. General circulation policies for private citizens: The practices of publicly supported academic libraries. In McCabe, G.B. (ed.). Academic Libraries in Urban and Metropolitan Areas. New York: Greenwood Press. 33-44

Nelson, S. and Garcia, J. 2003. Creating policies for results: From chaos to clarity. Chicago: American Library Association.

Inkanyiso, Jnl Hum \& Soc Sci 20I I, 3(I) 
Neuendorf, K. 2002. The content analysis guidebook. Thousand Oaks, CA: Sage Publications.

Powell, R. 2004. Basic research methods for librarians. $4^{\text {th }}$ ed. Westport: Libraries Unlimited.

Russel, R.E., Robison, C.L., Prather, J.E. and Carlson, C.E. 1992. External user access to academic libraries in urban/ metropolitan areas. In G.B. McCabe (ed.). Academic Libraries in Urban and Metropolitan Areas. New York: Greenwood Press. 27-32.

Smith, G., Street, K., and Wales, T. 2007. An online library service for Open University MBA alumni - challenges and opportunities. Journal of Librarianship and Information Science 39 (3): I62-I76.

Sung, M., and Yang, S. 2009. Student-University Relationships and Reputation: A Study of the Links between Key Factors Fostering Students' Supportive Behavioral Intentions towards Their University. Higher Education: The International Journal of Higher Education and Educational Planning 57 (6): 787-8I I.

University of Wisconsin System. 2000. Exhibit I: Budget allocations by cluster, institution and program (all funds). Redbook 2000-200I. Madison, WI: University of Wisconsin System.

University of Wisconsin System. 2010. Exhibit I: Budget allocations by cluster, institution and program (all funds). Redbook 2010-201 I. Madison, WI: University of Wisconsin System.

Waggoner, J.P, Jr. 1964. The role of the private university library. North Carolina Libraries 22: 55-57.

Wells, C. 2006. Alumni access to research databases: The time is now. College \& Research Libraries News 67 (7): 4I3-4I6.

Wetherill, H. 2008. To boldly go - creating an online library for alumni. Serials 2 I (3): 20I-204.

Yin, R. 2003. Case study research: Design and Methods. $3^{\text {rd }}$ ed. Thousand Oaks, CA: Sage Publications. 